BookReview

\title{
Islamic Society in Practice
}

\section{Carolyn Fluehr-Lobban. Gainesville: University of Flor- ida Press, 1994, 201 pp.}

Islamic Society in Practice is written in a new tradition of Western scholarship on Islam that seeks to represent an altemative view to that of Orientalism. The author sets out to analyze Islam as lived and practiced in everyday life, and brings out the human dimension of a region and a religious tradition that largely have been stereotyped in the West. Without advocating conversion or the bluming of differences, she argues that approaching Islamic and Arab cultures on their own terms and recognizing their strengths and weaknesses will produce the crosscultural understanding necessary for world peace in the twenty-first century.

The book, the result of more than two decades of research and over five years of residence in Khartoum, Cairo, and Tunis, covers a wide range of subjects. Among these are the five pillars of Islam, Islamic values and social practice, family and gender relations, the ongoing debate on the reform of family law, Islamic identities in a changing world, and the sociopolitical dimensions of contemporary Islamic movements.

The author's study of Islam and her residence among and close interaction with Muslims accorded her considerable access to Islamic culture and enabled her to debunk tenured stereotypes. She gives a very intimate picture of the ethos of Muslim societies and pays special attention to the structure of the extended Muslim family and the status of women in Islamic societies. In a bid to explode the myth of the oppressed Muslim woman, she goes beyond facile observations to look at the deeper social and ethical logic that informs apparent genderbased discrepancies in Islamic laws and practices. She also documents facts about the strides that Muslim women have been making that never make it to the headlines: For instance, many major universities in the Middle East, such as Cairo University, have about 50 percent female students, and until recently, there was a greater proportion of female medical doctors and engineers in Arab Muslim societies than in the West.

The author is also evenhanded in her analysis of the struggle in many Muslim countries today between secularists and Islamists. She sets up a dialogue between the contending parties, thus allowing the reader to hear their opposing points of view. Arguably, the greatest documentary value of the work is the analysis of the history and character of the Islamist movements in Egypt, Sudan, and Tunisia, as well as the problems that each of these countries continues to face in its attempts to reform family law. 
The study does have some problems, the first of which is methodological. The book sets out to make "accessible to a Western audience the lives of the everyday people of the Arab and Muslim worlds" (p. 2). In reality, however, the study is focused on only three countries of the Arab world. This has led the writer to make essentialist generalizations about Muslim societies based on her experiences in Sudan, Egypt, and Tunisia. A study that purports to study Islam as lived by ordinary people would be more viable if it were actually based on the observation of Islam in the different cultural zones of the Muslim world.

In addition, Fluehr-Lobban's work has some factual and linguistic errors. The notion that the age at which a Muslim starts to observe the fast of Ramadan is a matter of personal choice (p. 28) and that, for Sunni Muslims, the authoritative word regarding the commencement of Ramadan comes from Saudi Arabia (p. 31) is clearly misinformed. Equally misinformed is the view that the Islamic interpretation does not reject the double standard in patriarchal societies, which, in the case of adultery sanctions, means that the penalty falls on the accused woman "and not on the man with whom she is accused to have had sexual relations" (p. 55). The author's reference to Saudi Arabia, Iran, and Sudan as Islamic republics is also problematic.

She does, however, give a very interesting account of her study of Arabic. And it is commendable that she transcribes into the Latin alphabet some key Arabic phrases that Muslims utter frequently. While such transliterated utterances give an impression of authenticity, in most cases she transliterates them incorrectly. Examples are: bismiAllah (p. 24), WaMuhammadun Rassoul Allah (pp. 23-24). Some of the transliterations, beyond being grammatically incorrect, distort the meaning that the utterances are intended to convey. Perhaps the most outstanding of these culturally sensitive errors are the utterances La illallah (p. 23) and Ashadu ann la Allah ila Allah (p. 24).

The above methodological, factual, and transliteration problems cannot detract seriously from the value of Islamic Society in Practice. The author has succeeded in dispelling some of the widely held misconceptions about Islam and Muslim-Arab societies. Perhaps the most refreshing aspect of her work is the total lack of ideological hostility to Islam. Although her personal voice resonates throughout the work, it is a voice that is more eager to learn than to judge, a voice that brings out the very personal and human quality of her fieldwork among people that she and her family have come to live with and love and whose lives have become interwoven so beautifully with her own personal life narrative.

Ahmed Sheikh Bangura Department of Modern and Classical Languages University of San Francisco San Francisco, California 